\title{
Proficient Understudy of Copper Slag as Fine Aggregate in Portland Pozzolana Cement
}

\author{
S.Sakthivel ${ }^{1 *}$ M.Velumani $^{1}$ K.Yuvaraj ${ }^{1}$ \\ ${ }^{1}$ Assistant Professor, Department of Civil Engineering, K.S.Rangasamy College of Technology, Tiruchengode,Tamil \\ Nadu, India. \\ *Corresponding author E-Mail ID: sakthi200888@gmail.com \\ Doi: https://doi.org/10.34256/irjmtcon59
}

\begin{abstract}
Copper slag obtained during smelting to extract copper metal from the ore. The review of the characteristics of copper slag encourages several applications such as for manufacture of cement, in aggregates, Landfill, glass, tiles etc. Many researchers have already found it is possible to use copper slag as a concrete aggregate. The workability and strength characteristics were assessed through a series of test on different mix proportions at $10 \%$ incremental copper slag by weight replacement of sand. M35 grade concrete was used and the tests were conducted for various

proportions of copper slag replacement with sand of $0 \%, 10 \%, 20 \%, 30 \%, 40 \%, 50 \%, 60 \%, 70 \%, 80 \%, 90 \%, 100 \%$ in concrete. Then the concrete where cured for 7, 28, 60 and 90 days. Then they were tested for compressive strength, split tensile strength, and flexural strength. Finally the results were compared with the concrete made with the Portland Pozzolana cement (PPC) and fine aggregate (sand).
\end{abstract}

Keywords: Copper slag, PPC, compressive strength, split tensile strength and flexural strength.

\section{INTRODUCTION}

The development of construction material have posed problem and challenges that initiated worldwide research programs and continued conventional and non-conventional application leading ultimate economy. Researchers developed waste management strategies to apply for advantages for specific needs. Therefore, now a day's incorporation of secondary material is being encouraged [1]. The government of India has targeted to reduce the industrial by product from the disposal. Harmful effects of concrete on environment can be reduced by producing good and durable concrete by using industrial by product [2]. Where copper slag is one the waste material which can be used as the replacement of find aggregate in construction which will reduce damage to the environment due to the waste resulting from the copper manufacturing process and helps in saving natural resources [3].

\section{MATERIAL AND SOURCES}

Material collection is the important step in the project. The material for the project is obtained from various resources is tabulated below.1. 
Table1. Material And Sources

\begin{tabular}{|c|c|c|}
\hline S.No & Materials & Source \\
\hline 01 & Cement & Ultra tech cement \\
\hline 02 & Fine aggregate & Karur sand \\
\hline 03 & Copper slag & Sterilite industries, Tuticorin, \\
\hline 04 & Coarse aggregate & Rock gravel \\
\hline
\end{tabular}

\section{BULK DENSITY}

The bulk density gives valuable information regarding the shape and grading of the material. The bulk density of copper slag is more of about 2.21 where for fine aggregate it is 1.53 . Higher the bulk density lower is the void content to be filled by sand and cement. The sample which gives the supreme bulk density is taken as right sample for making economical mix.

\section{WATER ABSORPTION}

Water absorption is less in copper slag of about 0.41 where fine aggregate of about 7 . Lesser the water absorption more will be the durability of concrete.

\section{SPLIT TENSILE TEST}

For testing split tensile strength concrete cylinder of size $150 \mathrm{~mm}$ diameter and $300 \mathrm{~mm}$ height were casted with different percentage of copper slag. The mould where properly cleaned and oiled then the concrete is filled in three layer then each layer is compacted using tamping rod. It is cured for 7, 28, 60 and 90 days. The load is applied until the failure occurs and failure lode is noted. The split tensile strength is calculated using the formula

\section{Split tensile strength $=\mathbf{2 P} / \boldsymbol{\pi L D}$}

Where,

\section{$\mathbf{P}=$ Failure load}

\section{D=Dia of cylinder}

\section{$\mathrm{L}=$ Length of cylinder}

The split tensile strength for various percentage of copper slag Table. 2 given below.

Table.2.Split Tensile Of Cylinder

\begin{tabular}{|c|c|c|c|c|c|}
\hline \multirow{2}{*}{ S.No } & \multicolumn{2}{|l|}{ Specimen } & \multicolumn{3}{|c|}{$\begin{array}{r}\text { Split Tensile Strength } \\
\left(\mathbf{N} / \mathbf{M m}^{2}\right.\end{array}$} \\
\cline { 2 - 6 } & FA & CS & $\mathbf{7}^{\mathbf{T H}}$ DAY & $\mathbf{2 8}^{\mathbf{T H}}$ DAY & $\mathbf{6 0}^{\mathbf{T H}}$ DAY \\
\hline 1 & 100 & 0 & 4.23 & 4.89 & 5.29 \\
\hline 2 & 90 & 10 & 5.01 & 5.17 & 5.86 \\
\hline 3 & 80 & 20 & 5.13 & 6.23 & 6.37 \\
\hline 4 & 70 & 30 & 5.29 & 6.93 & 6.96 \\
\hline 5 & 60 & 40 & 6.24 & 7.25 & 7.89 \\
\hline
\end{tabular}




\begin{tabular}{|c|c|c|c|c|c|}
\hline 6 & 50 & 50 & 6.02 & 7.02 & 7.85 \\
\hline 7 & 40 & 60 & 5.17 & 6.13 & 7.11 \\
\hline 8 & 20 & 80 & 4.19 & 5.09 & 6.21 \\
\hline 9 & 0 & 100 & 3.03 & 3.10 & 4.17 \\
\hline
\end{tabular}

From the Fig.1 the split tensile strength of concrete with $40 \%$ surrogating fine aggregate by copper slag has the maximum split tensile strength. In that $7^{\text {th }}$ day, $28^{\text {th }}$ day, $60^{\text {th }}$ day and $90^{\text {th }}$ day. On surrogate concrete the 7th day split tensile strength is $6.24 \mathrm{~N} / \mathrm{mm}^{2}$ where the conventional concrete is about $4.23 \mathrm{~N} / \mathrm{mm}^{2}$. In $28^{\text {th }}$ day it is about $7.25 \mathrm{~N} / \mathrm{mm} 2$ where conventional concrete is about $4.89 \mathrm{~N} / \mathrm{mm}^{2}$. In $60^{\text {th }}$ and $90^{\text {th }}$ day it is about $7.89 \mathrm{~N} / \mathrm{mm}^{2}$ and $8.06 \mathrm{~N} / \mathrm{mm}^{2}$ where the conventional concrete is $5.29 \mathrm{~N} / \mathrm{mm}^{2} 6.02 \mathrm{~N} / \mathrm{mm}^{2}$. The replaced concrete has more split tensile strength than the conventional concrete. Above $40 \%$ replacement of copper slag the split tensile strength start decreasing but $50 \%, 60 \%$ and $80 \%$ of copper slag replacement gives more split tensile strength than the conventional concrete.From the result we can clinch that split tensile strength is increased at $40 \%$ replacement of fine aggregate by copper slag.

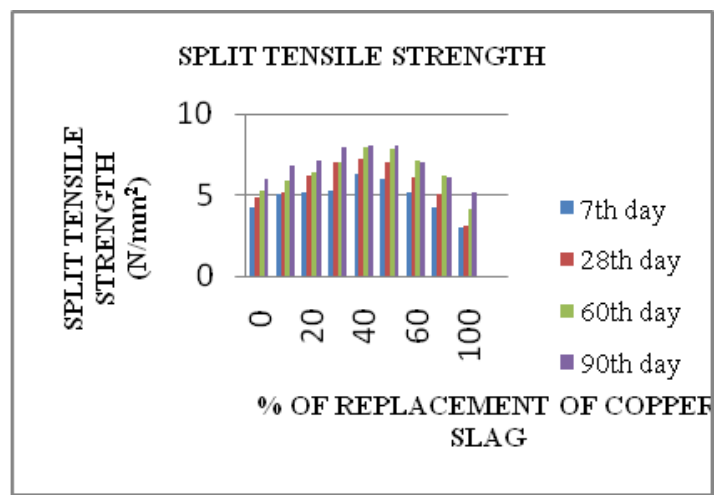

Fig.1.Replacement \% Vs Split Tensile Strength

\section{FLEXURAL TEST}

In order to determine the flexural strength of beam size $1000 \times 150 \mathrm{~mm}$ is casted using various percentage of copper slag. It is allowed to cure for 7, 28, 60, 90 days. The UTM testing machine may be set to any reliable type of sufficient capacity.three point load is given to the specimen until the failure occure and the load is noted.

$$
\mathbf{F}_{\mathrm{cr}}=\mathbf{P L} / \mathbf{B D}^{2} \quad \text { Where, }
$$

$\mathrm{F}_{\mathrm{cr}}=$ modulus of rupture

$\mathrm{P}$ = ultimate load in $\mathrm{N}$

$\mathrm{L}=$ length of beam in $\mathrm{mm}$

$\mathrm{B}=$ Average width of specimen in $\mathrm{mm}$

$\mathrm{D}=$ Average depth of specimen in $\mathrm{mm}$

The flexural strength of beam is Tabulated below in 3

Table.3. Flexural Strength of Beam

\begin{tabular}{|l|l|l|l|l|l|l|}
\hline S.No & \multicolumn{5}{|l|}{ Specimen } & \multicolumn{5}{l|}{ Fiexural Strength Of Beam $\left(\mathrm{N} / \mathrm{Mm}^{2}\right)$} \\
\cline { 2 - 7 } & FA & CS & $7^{\text {th }}$ DAY & $28^{\text {th }}$ DAY & $60^{\text {th }}$ DAY & $90^{\text {th }}$ DAY \\
\hline
\end{tabular}




\begin{tabular}{|l|l|l|l|l|l|l|}
\hline 1 & 100 & 0 & 4.13 & 5.06 & 6.13 & 6.89 \\
\hline 2 & 90 & 10 & 4.28 & 5.17 & 6.89 & 7.04 \\
\hline 3 & 80 & 20 & 5.01 & 6.81 & 7.23 & 8.23 \\
\hline 4 & 70 & 30 & 5.77 & 7.13 & 7.81 & 8.01 \\
\hline 5 & 60 & 40 & 6.14 & 7.92 & 8.28 & 8.49 \\
\hline 6 & 50 & 50 & 5.98 & 7.01 & 7.05 & 7.13 \\
\hline 7 & 40 & 60 & 5.03 & 6 & 6.81 & 6.23 \\
\hline 8 & 20 & 80 & 4.89 & 5.29 & 6.01 & 5.89 \\
\hline 9 & 0 & 100 & 4.23 & 4.1 & 5.01 & 5.43 \\
\hline
\end{tabular}

From the Fig. 2 the flexural Strength of concrete with $40 \%$ surrogating fine aggregate by copper slag has the maximum flexural strength on $7^{\text {th }}$ day, $28^{\text {th }}$ day, $60^{\text {th }}$ day, $90^{\text {th }}$ day. On $7^{\text {th }}$ day the split tensile strength is $6.14 \mathrm{~N} / \mathrm{mm}^{2}$. On $28^{\text {th }}$ day it is about $7.92 \mathrm{~N} / \mathrm{mm} 2$. Whereas on $60^{\text {th }}$ and $90^{\text {th }}$ day it is about $8.28 \mathrm{~N} / \mathrm{mm}^{2}$ and $8.49 \mathrm{~N} / \mathrm{mm}^{2}$. The replaced concrete has more flexural strength which is more than the conventional concrete.

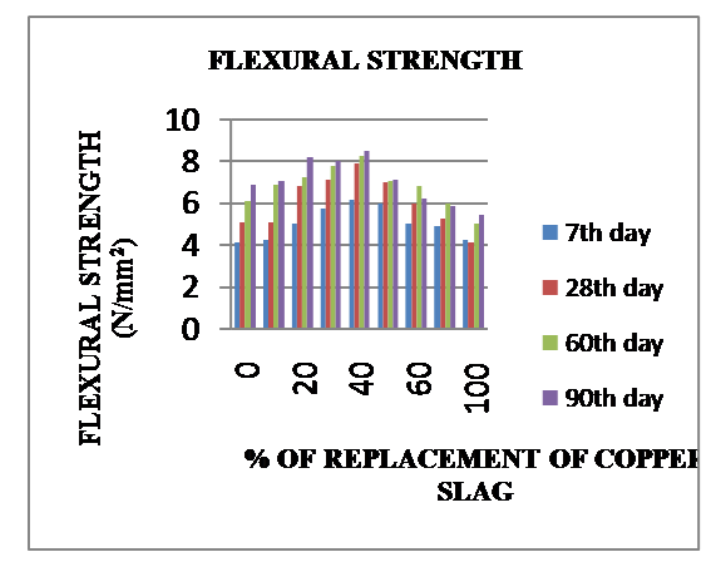

Fig.2.Replacement \% vs Flexural Strength

From the result we can clinch that flexural strength is increased at $40 \%$ replacement of fine aggregate by copper slag

\section{CONCLUSION}

1. The sieve analysis test proves that the copper slag can be surrogateded for fine aggregate in concrete.

2. Water absorption in replaced concrete is lower than the conventional concrete.

3. As the surrogation of copper slag increases the workability of concrete decreases due to free water left in the concrete.

4. The copper slag has more specific gravity than fine aggregate which provide density to the concrete

5. The compressive strength on concrete increased by surrogating fine aggregate by $40 \%$ of copper slag

6. By surrogating $40 \%$ of fine aggregate by copper slag the split tensile strength is increased.

7. The flexural strength higher by $40 \%$ replacement of fine aggregate by copper slag. 
S. Sakthivel et al. / International Research Journal of Multidisciplinary Technovation /2019, 1(6), 427-431

8. Replacement of copper slag increases the self weight of concrete to the maximum of 15 to $20 \%$.

\section{REFERENCES}

1. Meenakashi sundarivizhi. S, Illangovan.R,' Performance of copper slag and ferrous slag as partial replacement of sand in concrete', International journal of civil and structural engineering. Volume 1, No 4(2011).

2. Fly ash: A resource material for innovation building material- India perspective C.N.Jha and J.K.Prasad.

3. Alnuaimi.A.S, 'Use of copper slag as a replacement for fine aggregate in reinforced concrete slender columns'.

4. Bipra gorai, R.K.Jana, Premchand, "Characteristics and utilisation of copper slag- a review". Resources, Conservation and Recycling 39 92003) pp. 299-313.

5. D.Brindha, et al 'Durability studies on copper slag admixture concrete', International journal of civil and structural engineering, vol-1, no 2, (2010).

6. Khalife S. Al-Jabri, et al ' Performance of high strength concrete made with copper slag as fine aggregate', construction and building material vol-23 (2009).

7. N.K.S.Pundhir, et al ' Use of copper slag as construction material in bituminous pavements', Journal of Scientific \& Industrial Research, vol 64 (2005).

8. R.R.Chavan and D.D.Kurkarni,' Performance of copper slag on strength properties as partial replace of fine aggregate in concrete mix design.

9. Gupta .R.C,Blessen Skariah Thomas,' Utilisation of copper slag and discarded rubber tyres in concrete', International Journal of Civil and Structural Engineering, vol 3,(2012).

10. Arivalagan.s, 'Effect of copper slag as fine aggregate on reinforced concrete beam', International journal of civil and structural engineering, vol 2, (2013).

11. Khalife S. Al-Jabri, et al ' Performance of high strength concrete made with copper slag as fine aggregate', construction and building material vol-23 (2009).

12. Jagadesh. Sunku,' Advantages of using fly ash as supplementary cementing material (SCM) in fibre cement sheet'. 